УДК 346.3

DOI https:// doi.org/10.32837 / yuv.v0i6.2039

\author{
С. Подоляк, \\ кандидат юридичних наук, \\ доцент кафедри господарського та адміністративного права \\ факультету соціології та права \\ Національного технічного університету України «Київський політехнічний інститут \\ імені Ігоря Сікорського»
}

\title{
ПРОБЛЕМИ ПРАВОВОГО РЕГУЛЮВАННЯ ДОГОВОРУ АУТСОРСИНГУ В УКРАЇНІ
}

Стрімкий розвиток ринкових відносин характеризується наявністю конкуренції, яка вимагає від учасників ринку постійного пошуку нових виробничих можливостей, удосконалення технологій, зменшення затрат, але одночасного підвищення якості продукції або послуг, які надаються. Це зумовлює необхідність використання такого правового інструментарію, як аутсорсинг, - залишати собі тільки те, що вмієш робити краще за інших сконцентрувати господарську діяльність на вирішенні ключових питань, а зовнішньому виконавцю віддати другорядні функції - те, що він робить краще за інших. Особливо це стає актуальним в умовах світової кризи.

Метою статті є визначення правової сутності категорії «господарський договір аутсорсингу», його особливостей та проблем правового регулювання шляхом проведення аналізу чинного законодавства України у сфері аутсорсингу і формулювання пропозицій щодо його удосконалення.

Термін «аутсорсинг» походить з англійської мови, де він складається із трьох слів «outside resource using», що можна перекласти як «використання зовнішніх джерел (ресурсів)». У США діє Інститут аутсорсингу, який визначає аутсорсинг як організаційне рішення 3 передачі третій особі - сторонньому підряднику деяких бізнес-функцій або окремих бізнес-процесів організації [1]. Використання аутсорсингу передба- чає отримання послуг. Метою застосування аутсорсингу є використання передових бізнес-технологій для утримання конкурентних переваг, а також відвойовування позицій у конкурентній боротьбі. 3 практичної точки зору аутсорсинг дає змогу використовувати власні ресурси організації для виконання тих функцій, в яких вона $€$ найсильнішою й вони формують ї конкурентні переваги, у той час як зовнішня сторона (аутсорсер) буде виконувати функціі, в яких власне вона $є$ фахівцем. Тобто аутсорсинг - це довгострокова, орієнтована на результат співпраця із зовнішнім постачальником послуг у тій частині діяльності, яка традиційно виконувалась всередині самої організації. Така співпраця дає змогу вивести за межі основної діяльності організації непрофільні бізнес-процеси та сконцентрувати ресурси на основному виді діяльності, що дає змогу економити час, ресурси, підвищувати ефективність бізнесу, але не завжди дає змогу зменшувати затрати.

Взагалі ідея аутсорсингу використовувалась ще на початку XX ст. топ-менеджерами автомобільних гігантів у США - Генрі Фордом та Альфредом Слоуном.

Як приклад застосування аутсорсингу сьогодні можна навести той факт, що багато виробників брендового одягу відмовляються від володіння фабриками пошиття в Європі, а передають його пошиття на аутсор- 
синг у компанії, які мають фабрики пошиття одягу у країнах, де вартість робочої сили $€$ низькою. Так само роблять компанія Apple (ii телефони виготовляються у Тайвані і Китаї) та інші компаніі. Можна зарахувати до аутсорсингу також послуги, які надають приватні військові компаніiі, наприклад, Academi (колишня назва - Blackwater), яка фактично надавала та надає США та іншим країнам та приватним особам бойові підрозділи, сформовані 3 колишніх спецпризначенців, для виконання різноманітних завдань, у тому числі у «гарячих точках». У Великобританіі, наприклад, віддаються на аутсорсинг медичні послуги, такі як швидка допомога, обслуговування медичних будівель, харчування в медичних закладах тощо.

Міжнародна організація зі стандартизаціï ISO в 2003 р. створила «Посібник із застосування процесів аутсорсингу» ISO/TC $176 / \mathrm{SC} 2 / \mathrm{N}$ 630R2 [2]. Мета цього документа полягає в тому, щоб надати керівні вказівки щодо застосування пункту 4.1 стандарту ISO 9001:2000 щодо управління процесами аутсорсингу, а саме: «якщо організація вирішує передати стороннім організаціям виконання будь-якого процесу, який має вплив на відповідність продукції певним вимогам, то організація має забезпечувати контроль над такими процесами. Управління такими процесами має бути визначено в системі менеджменту якості».

В Україні вперше офіційне визначення терміна «аутсорсинг» з'явилось у банківський діяльності. Національний банк України Постановою Правління НБУ «Про схвалення Методичних рекомендацій щодо організації та функціонування систем ризикменеджменту в банках України» від 02.08.2004 р. № 361 визначив аутсорсинг як виконання певних функцій i робіт, які традиційно $€$ «внутрішніми» i виконуються штатними працівниками шляхом залучення зовніш- ніх незалежних сторін на договірній основі; аутсорсинг використовується для оптимізації витрат i процесів у банку [3].

Визначення аутсорсингу також надається в Національному класифікаторі України «Класифікація видів економічної діяльності» (розділ 4), затвердженого наказом Держспоживстандарту України від 11.10.2010 р. № 457: аутсорсинг-угода, згідно з якою замовник доручає підряднику (аутсорсеру) виконати певні завдання, зокрема виробничий процес або повний виробничий процес, надання послуг щодо підбирання персоналу, допоміжні функціі [4]. Термін «аутсорсинг» також використовується, якщо підрядник (аутсорсер) здійснює допоміжну діяльність, незалежно від того, чи виконують такі завдання на ринкових умовах. Замовник і підрядник (аутсорсер) можуть бути розташовані в межах однієї економічної території чи в різних економічних територіях. Фактичне місцезнаходження не впливає на класифікацію цих суб'єктів.

3 огляду на те, що визначення поняття «аутсорсинг» в Україні законодавчо не закріплене, науковці мають різні концептуальні підходи, i досі не вироблено єдиної точки зору щодо правової природи договору аутсорсингу і його місця в правовій системі. Ми спробуємо зробити аналіз правової сутності аутсорсингу на базі авторського визначення господарського договору як соціально-правової господарської системи, заснованої на угоді сторін, що слугує юридичною (правовою) підставою виникнення зобов'язальних правовідносин, за якими визнається юридичний (правовий) характер, та спрямованої на досягнення правової та економічної мети [5, с. 21].

Суттєвою ознакою господарських договорів $є$ ї універсальна конструкція як засобу організації суспільних відносин, основними елементами якої $€$ контрагенти, істотні умови 
договору, угода сторін, зобов'язальні правовідносини, правова та економічна мета договору [5, с. 17-18]. Розглянемо договір аутсорсингу з правової точки зору, враховуючи запропоновану нами конструкцію:

- договір аутсорсингу укладається юридичними особами -господарюючими суб’єктами у сфері господарювання;

- договір є двостороннім, оскільки сторонами договору $€$ замовник та аутсорсер;

- істотними умовами договору $є$ умова про предмет (предмет договору детально відображається в договорі та узгоджується сторонами), вартість наданих послуг, у разі невиконання договору однією з сторін вона має нести відповідальність, ступінь відповідальності та порядок здавання-прийняття наданих послуг також узгоджуються сторонами;

- підписаний акт здавання-приймання наданих послуг $є$ підставою для розрахунку.

Таким чином, можна зробити висновок, що договір аутсорсингу $€$ різновидом господарського договору. Наш висновок збігається з позицією А.В. Фадєєва, який також вважає, що договір аутсорсингу має всі характеристики, щоб бути названим господарським договором [6, с. 112].

У своїй книзі Дж. Брайан Хейвуд розглядає аутсорсинг як процес переведення одного чи кількох підрозділів підприємства або всіх пов'язаних із ним активів в організацію постачальника послуг, який пропонує надати певну послугу протягом певного часу за визначену ціну [7].

Нині в Україні договору аутсорсингу, який має гнучку конструкцію, досі не знайшлось місця ні в системі господарського, ні в системі цивільного права при тому, що зріст об'ємів послуг аутсорсингу постійно зростає.

Господарський Кодекс України в ст. 6 серед загальних принципів господарювання визначає вільний рух капіталів, товарів та послуг на терито- рії України і необхідність забезпечення добросовісної конкуренції у підприємництві, а в ч. 1 ст. 259 виокремлює надання послуг як різновид господарської діяльності. Цивільний кодекс України в ч. 1 ст. 901 нормативно закріплює загальне визначення договору про надання послуг як цивільно-правової категорії, а в ч. 2 визнає їню різноманітність, при цьому значну роль у правовому регулюванні віддає саме змісту певного договору.

Враховуючи все вищезазначене, ми вважаємо, що договір аутсорсингу потребує виокремлення його як правової категорії - господарський договір надання послуг аутсорсингу й окремого правового регулювання. При цьому складність його правового регулювання полягає в особливостях його застосування в різних сферах виробничих, сервісних, фінансових, інформаційних, технологічних, організаційних, фінансово-економічних, маркетингових тощо.

В Україні, ймовірно, першими аутсорсерами були юридичні особи, які надавали охоронні послуги. Розвиток ринку маркетингових послуг зумовив виникнення юридичних осіб-аутсорсерів для надання послуг маркетингу, потім аутсорсинг бухгалтерських послуг, IT-аутсорсинг тощо.

До переваг використання аутсорсингу можна зарахувати економію часу, зменшення витрат, концентрацію керівництва на ключових питаннях, задачах та видах діяльності, підвищення якості робіт, які виконуються, більшу пристосованість організації до змін на ринку.

Розглянемо типові передумови виникнення потреби залучання аутcopcepiв:

- необхідність певних ресурсів для виконання проектів;

- вивільнення часу топ-менеджерів, які мають займатися стратегічним управлінням, а не вирішенням повсякденних операційних питань;

- відсутність певних технічних знань для реалізації проектів; 


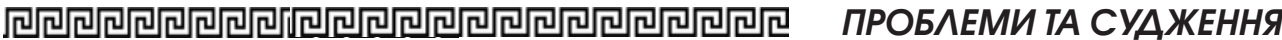

- необхідність у стандартизованому технічному обслуговуванні всіх філіалів компанії, які можуть навіть знаходитись у різних країнах;

- необхідність в удосконаленні бізнес-процесів за допомогою аутсорсера, який може проаналізувати та надати рекомендації щодо удосконалення бізнес-структури, бізнес-процесів організаціі.

Однак застосування аутсорсингу має свої недоліки: певні проблеми в процесі координації та контактування; питання контролю; ймовірність виникнення конфліктів, забезпечення безпеки даних, залежність від аутсорсера, а також вартість його послуг.

Крім недоліків, можна виокремити i ризики застосування аутсорсингу: недотримання аутсорсером строків, можливість послаблення або втрати контролю над процесом або аутсорсером, фінансовий стан аутсорсера.

Існують також випадки виникнення ситуацій, коли організація, яка укладає договір аутсорсингу, може зробити певні помилки, наслідком яких може бути те, що застосування аутсорсингу не призведе до очікуваного результату. Наведемо такий приклад: організація намагалась налагодити всередині себе певний бізнес-процес, але в неї це не вийшло. Віддаючи його на аутсорсинг, вона, ймовірно, не зможе правильно прописати умови договору таким чином, щоб його контролювати та отримати той результат, якій їй потрібен.

Договори аутсорсингу можна класифікувати за різними критеріями та признаками, що має практичне значення для правового регулювання

1. За видами аутсорсингу:

- аутсорсинг бізнес-процесів: бухгалтерський аутсорсинг; управління персоналом (кадровий аутсорсинг); маркетинговий аутсорсинг; юридичний аутсорсинг; аутсорсинг внутрішнього аудиту; виробничий аутсорсинг; інноваційний аутсорсинг;

- аутсорсинг у сфері послуг: логістичний (транспортний) аутсорсинг; аутсорсинг у сфері реклами; аутсорсинг у сфері громадського харчування; аутсорсинг у сфері послуг зв'язку (поштові, кур'єрські и телекомунікаційні); інформаційний аутсорсинг; аутсорсинг у сфері складування; аутсорсинг у сфері охоронної діяльності.

2. За формою аутсорсингу: повний (максимальний) аутсорсинг; частковий (вибірковий) аутсорсинг.

3. За галузевою належністю діяльності організації: промисловий аутсорсинг; інноваційний аутсорсинг; будівельний аутсорсинг; торговий аутсорсинг; туристичний аутсорсинг; транспортний аутсорсинг; банківський аутсорсинг.

4. Залежно від галузі аутсорсингу: професійний аутсорсинг; фінансовий аутсорсинг; адміністративний аутсорсинг; географічний аутсорсинг; виробничий аутсорсинг; технологічний аутсорсинг.

5. Залежно від часу виконання послуг аутсорсингу: довгостроковий аутсорсинг; строковий (одноразовий) аутсорсинг; сезонний аутсорсинг.

Фахівці Інституту аутсорсингу США виокремлюють як основні такі види аутсорсингу:

1) виробничий аутсорсинг, при якому компанія віддає частину свого виробничого циклу або повністю весь виробничий цикл сторонній компанії з метою подальшої взаємодії в межах аутсорсингу;

2) ІТ-аутсорсинг (лідер у цьому сегменті) полягає в передачі сторонній організації повністю або частково функцій $з$ обслуговування інформаційних потреб підприємства: налаштування техніки, консультування користувачів, установка та супровід бухгалтерських та кадрових програм, офісного ПО тощо;

3) аутсорсинг бізнес-процесів (BPO business process outsourcing) являє собою аутсорсинг багаторівневих процесів, які зазвичай пов'язані з управлінням фінансами, персоналом, маркетингом, юридичним 
забезпеченням, бухгалтерським обліком, рекламою тощо [1].

Під час визначення відповідного рівня управління процесом аутсорсингу зазвичай виокремлюють дві ситуації:

а) якщо організація володіє відповідною компетентністю і здатна сама виконувати процес, але при цьому вибирає процес аутсорсингу (з комерційних або інших міркувань). У такій ситуації критерії управління мають бути визначені попередньо і в разі потреби перетворені на вимоги для постачальника процесу аутсорсингу;

б) якщо організація не має відповідної компетентності для виконання процесу своїми силами i приймає рішення щодо вибору процесу аутсорсингу. У такій ситуації має бути впевненість, що заходи з управління процесом аутсорсингу, запропоновані постачальником, є адекватними. У деяких випадках необхідне залучання зовнішніх фахівців для оцінки адекватності цих заходів. При цьому бажано (навіть доцільно) в договорі між організацією та постачальником визначати вибіркові або всі методи, які необхідно використовувати для управління процесом аутсорсингу. У роботі з постачальником необхідно виявляти обережність, але вона не має применшувати ініціативу удосконалення процесу аутсорсингу. У деяких ситуаціях неможливо перевірити кінцевий результат процесу аутсорсингу контролем або вимірюванням. У таких випадках організація має гарантувати, що управління процесом аутсорсингу включає валідацію процесу відповідно до пункту 7.5.2 ISO 9001:2000 «Валідація процесів».

Очевидно, що проводити оцінку ефективності та доцільності аутсорсингу необхідно задля уникання помилок у процесі його використання i, головне, цю оцінку необхідно проводити до укладення договору аутсорсингу. Після упровадження аутсорсингу в бізнес необхідно відслідковувати роботу компанії задля того, щоб зробити висновки і надалі уникати помилок і недоліків, усунути слабкі сторони.

Підсумовуючи вищевикладене, можна стверджувати, що незважаючи на труднощі, які виникають внаслідок відсутності правової бази у сфері аутсорсингу, переваги його очевидні i для успішного його застосування необхідне створення відповідних умов, тобто законодавче закріплення задля підвищення культури договірних відносин. Дослідження правової сутності договору аутсорсингу дає змогу підтверджувати доцільність його виокремлення як правової категорії в ГК України як господарського договору надання послуг аутсорсингу. Тільки чітка регламентація господарського договору аутсорсингу на законодавчому рівні буде сприяти його поширенню на території України та сприяти підвищенню ефективності бізнесу.

У статmі проводиться дослідження правової сутності договору аутсорсингу, його місия в законодавстві України. Здійснюеться аналіз правової природи договору аутсорсингу на базі авторського підходу до універсальності конструкиіі господарського договору. Доведено, що правова сутність господарського договору аутсорсингу повністю збігаеться із запропонованим нами визначенням господарського договору як соціально-правової господарської системи, сформульовано його визначення як правової категорії- господарський договір надання послуг аутсорсингу.

Проведений аналіз наявних, у тому числі в міжнародній практиці, підходів до застосування аутсорсингу дав змогу визначити основні переваги, недоліки, ризики. До основних переваг належать економія часу, зменшення витрат, концентрація керівництва на ключових питаннях, задачах та видах діяльності, підвищення якості 
робіт, які виконуються, більша пристосованість організаціі до змін на ринку. Серед головних недоліків визначаються можливість виникнення проблем у координаиіi та контактуванні, питання контролю, ймовірність виникнення конфліктів, забезпечення безпеки даних, залежність від аутсорсера, а також вартість його послуг. Особливістю застосування аутсорсингу є також можливість виникнення ризиків застосування аутсорсингу: недотримання аутсорсером строків, можливість послаблення або втрати контролю над проиесом або аутсорсером, фінансовий стан aутсорсера.

Договори аутсорсингу можна класифікувати залежно від різних критеріїв та ознак, щз має практичне значення для правового регулювання: за видами аутсорсингу, за формою аутсорсингу; за галузевою належністю діяльності організації; залежно від галузі аутсорсингу; залежно від участі в уставному капіталі; залежно від часу виконання послуг аутсорсингу. Надано рекомендаціі щодо обрання відповідного рівня процесу аутсорсингу для оцінки ефективності та доцільності його застосування.

Проведений аналіз чинного законодавства у сфері надання послуг довів доцільність виокремлення господарського договору надання послуг аутсорсингу як правової категорії в Господарському кодексі України та його законодавчого закріплення.

Ключові слова: господарський договір, надання послуг аутсорсингу, замовник, аутсорсер.

Podolyak S. Problems of legal regulation of outsourcing contract in Ukraine

The legal essence of the outsourcing contract, its place in the legislation of Ukraine are examined in the article.
The analysis of the legal nature of the outsourcing contract is carried out on the basis of the author's approach to the universality of the construction of the economic contract. It was proved that the legal essence of the economic contract of outsourcing completely coincides with our proposed definition of the economic contract as a socio-legal economic system. The definition of the economic contract of outsourcing services as a legal category was formulated.

The analysis of existing, including international practice, approaches to the use of outsourcing allowed to identify the main advantages, disadvantages, risks. The main advantages include: saving time, reducing costs, focusing management on key issues, tasks and activities, improving the quality of work performed, greater adaptability of the organization to changes in the market. Among the main disadvantages are: the possibility of problems with coordination and contact; control issues; the likelihood of conflicts, data security, dependence on the outsourcer, as well as the cost of its services. A feature of the use of outsourcing is also the possibility of risks of outsourcing: non-compliance with the deadlines of the outsourcer, the possibility of weakening or loss of control over the process or the outsourcer, the financial condition of the outsourcer.

Outsourcing contracts can be classified depending on various criteria and features, which has practical importance for legal regulation: by types of outsourcing, by form of outsourcing; by industry affiliation of the organization; depending on the field of outsourcing; depending on participation in the authorized capital; depending on the time of outsourcing services. Recommendations for choosing the appropriate level of outsourcing process to assess the effectiveness 
and feasibility of its application were proposed.

The analysis of the current legislation in the field of services proved the expediency of separating the economic contract for outsourcing services as a legal category in the Economic Code of Ukraine and its legislative consolidation.

Key words: economic contract, rendering outsourcing services, client, outsourcer.

\section{Література}

1. Outsourcing Institute URL: https:// outsourcing.com /

2. ISO 9000 Introduction and Support Package: Guidance on 'Outsourced Processes'. URL: https://www.iso.org/ files / live / sites / isoorg / files / archive/ pdf/en/05_guidance_on_outsourced_ processes.pdf

3. Про схвалення Методичних рекомендацій щодо організації та функціонування систем ризик-менеджменту в банках України : Постанова Правління НБУ від 02.08.2004 p. № 361. URL: https: / / zakon. rada.gov.ua/laws / show / v0361500-04\#Text 4. Наказ Держспоживстандарту України від 11.10.2010 р. № 457. URL: https: / / zakon.rada.gov.ua/rada/show/ v0457609-10\#Text

5. Подоляк С.A. Недійсний та неукладений господарський договір: правові підстави та наслідки. Монографія. Київ ; Видавництво Ліра-К, 2012. 214 с.

6. Фадєєв А.В. Правова природа договору аутсорсингу. Право і суспільство. 2013. № 6. C. 110-113.

7. J. Brian Heywood. Outsourcing Dilemma: The Search for Competitiveness. First Edition. 2001. 224 p. 